\title{
Infection control in residential care homes for the elderly in Hong Kong (2005-2014)
}

\author{
Grace CY Wong *, Tonny Ng, Teresa Li
}

\section{A B S T R A C T}

Introduction: This serial cross-sectional survey study aimed to review the trend in various infection control practices in residential care homes for the elderly (RCHEs) in Hong Kong from 2005 to 2014.

Methods: Annual cross-sectional surveys were conducted at all RCHEs in Hong Kong, including self-administered questionnaires, on-site interviews, inspections, and assessments conducted by trained nurses, from 2005 to 2014 . In all, $98.5 \%$ to $100 \%$ of all RCHEs were surveyed each year based on the list of licensed RCHEs in Hong Kong.

Results: There was a substantial increase in the proportion of RCHE residents aged $\geq 85$ years, from $40.0 \%$ in 2005 to $50.2 \%$ in 2014 ( $\mathrm{P}=0.002)$. The percentage of RCHE residents with special care needs also increased, from $22.3 \%$ in 2005 to $32.6 \%$ in 2014 for residents with dementia $(\mathrm{P}<0.001)$ and from $3.4 \%$ in 2005 to $5.0 \%$ in 2014 for residents with a long-term indwelling urinary catheter $(\mathrm{P}<0.001)$. The proportion of RCHEs with separate rooms for isolation areas ranged from $73.6 \%$ to $80 \%$ but did not show any significant trend over the study period.

This article was published on $10 \mathrm{Apr}$ 2019 at www.hkmj.org. The proportion of RCHEs with alcohol hand rub available showed an increasing trend from $25.4 \%$ in

2006 to $99.2 \%$ in 2014 ( $\mathrm{P}=0.008)$. The proportion of * Corresponding author: grace_cy_wong@dh.gov.hk Government, Hong Kong health or care workers (who were not the designated infection control officers) passing skills tests on hand washing techniques increased from $79.2 \%$ in 2006 to $91.5 \%$ in $2014(\mathrm{P}=0.02)$. An increasing trend was also observed for the proportion of infection control officers who were able to prepare properly diluted bleach solution, from $71.5 \%$ in 2005 to $92.2 \%$ in 2014 $(\mathrm{P}=0.002)$.

Conclusions: For infection control practice to continue improving, more effort should be made to enhance and maintain proper practice, and to mitigate the challenge posed by the high turnover rates of healthcare workers in RCHEs. Introduction of self-audits on infection control practices should be considered.

\section{Hong Kong Med J 2019;25:113-9}

https://doi.org/10.12809/hkmj187328

GCY Wong *, MB, ChB

T Ng, MMed (Public Health) Singapore, FHKAM (Community Medicine)

T Li, FFPH, FHKAM (Community Medicine)

Elderly Health Service, Department of Health, Hong Kong SAR

New knowledge added by this study

- From 2005 to 2014 , among residents of care homes for the elderly, the proportion of those aged $\geq 85$ years increased significantly.

- If this trend continues, the prevalence of co-morbidities and functional impairment will also continue to increase, leading to further infection control challenges.

- There have been improvements in infection control practices among residential care homes for the elderly in terms of manpower, facilities, practices, knowledge, and skills.

- The most obvious improvements have been in terms of manpower and facilities; more nurses and health workers were recruited, and more residential care homes for the elderly had made alcohol hand rub available. Correct hand washing techniques among health or care workers, availability of alcohol hand rub, and knowledge on the correct method to prepare diluted bleach solution have also improved over the years.

Implications for clinical practice or policy

- Improvements in infection control knowledge and skills among staff of residential care homes for the elderly have seemingly reached a plateau.

- Future infection control training should aim to support sustained compliance with proper practices, through the introduction of elements such as self-audits.

\section{Introduction}

\section{Residential care services for elderly people in Hong Kong}

In $2016,8.1 \%$ of elderly population in Hong Kong resided in non-domestic households (ie, residential care homes for the elderly [RCHEs], hospitals and penal institutions, etc). ${ }^{1}$ Residential care homes for the elderly are a heterogeneous group of institutions that provide varying levels of care for elderly people, who, for personal, social, health, or other reasons, can no longer live alone or with their families. 


\section{5年至2014年間香港安老院舍感染控制情況 黃頌欣、吳東尼、李敏碧}

引言：這項連續橫斷面調查研究旨在檢視2005年至2014年間香港的安 老院舍所採取的感染控制措施的趨勢。

方法：2005年至2014年期間於香港所有安老院舍進行年度橫斷面調 查, 包括自填問卷、現場面談、實地檢查及由受過訓練的護士進行評 估。根據香港持牌的安老院舍名單, 研究期間每年對 $98.5 \%$ 至 $100 \%$ 安 老院舍進行調查

結果：85歲或以上的安老院舍院友比例大幅增加, 由 2005 年的 $40.0 \%$ 增至 2014 年的 $50.2 \%(\mathrm{P}=0.002)$ 。有特別需要的安老院舍院友比例 也有所上升：患有認知障礙症的長者比例由 2005 年的 $22.3 \%$ 增至 2014 年的 $32.6 \%(\mathrm{P}<0.001)$, 長期使用留置導尿管的長者比例由 2005 年的 $3.4 \%$ 增至 2014 年的 $5.0 \%(\mathrm{P}<0.001)$ 。研究期間設有獨立房間 作為隔離區的安老院舍比例介乎 $73.6 \%$ 至 $80 \%$, 但無統計學上顯著的 趨勢。有提供酒精搓手液的安老院舍比例呈上升趨勢, 由 2006 年的 $25.4 \%$ 上升至 2014 年的 $99.2 \% （ P=0.008 ）$ 。以正確洗手方法通過感 染控制技巧評估非從事感染控制主任的保健員 / 護理員比例從 2006 年的 $79.2 \%$ 增至 2014 年的 $91.5 \%(\mathrm{P}=0.02)$ 。能調製正確稀釋度漂白 水的感染控制主任的比例亦從 2005 年的 $71.5 \%$ 上升至 2014 年的 $92.2 \%$ $(\mathrm{P}=0.002)$

結論：為繼續改善感染控制措施, 有關方面應作出更大努力, 加強及 維持正確程序的確切執行, 及減輕安老院舍醫護人員高流動率所帶來 的挑戰。應考慮引入感染控制實踐的自我審核機制。 in Hong Kong on infection control performance was conducted by VHTs between August and October 2003 as an enhanced measure in response to the severe acute respiratory syndrome (SARS) outbreak. Since then, annual assessments have been conducted by VHTs to assess and monitor the effectiveness of infection control measures and to identify the training needs of healthcare staff working in RCHEs, so as to plan for training activities for the following year. Assessment results are shared with relevant stakeholders, including the licensing authority and the community geriatric teams of public hospitals which provide outreach personal medical care to residents of RCHEs. Feedback is also provided to RCHE staff, to increase their alertness and encourage improvements.

This study aimed to review the 10-year trend in infection control practices in RCHEs in Hong Kong, based on results of the annual VHT assessments conducted from 2005 to 2014.

\section{Methods}

Assessment of all RCHE facilities, and the infection control knowledge and skills of staff are conducted annually via structured questionnaires and observational checklists.

\section{Sample size and coverage rate}

There is a mix of government-subvented, selffinanced, and privately run RCHEs in Hong Kong. All RCHEs must be licensed under the Residential Care Homes (Elderly Persons) Ordinance. The RCHEs operate according to the code of practice $(\mathrm{COP})^{2}$ issued by the licensing authority. The COP sets out guidelines, principles, procedures, and standards for the operation and management of RCHEs. A chapter in the COP is devoted to infection control, requiring the RCHE's operator to designate an infection control officer (ICO). The ICO must coordinate and implement infection control measures within the home according to the infection control guideline issued by the Centre for Health Protection of the Department of Health. ${ }^{3}$ Operators of RCHEs are required to report specific infectious disease cases and outbreaks to the authorities.

\section{Visiting health teams}

Eighteen visiting health teams (VHTs) are established under the Elderly Health Service of the Department of Health in Hong Kong. Comprising 47 nurses, the teams reach out into the community and residential care settings to conduct health promotion activities for the elderly people, and carers of elderly people, aiming to increase the health awareness and the selfcare ability of elderly people, and to enhance the quality of caregiving.

The first on-site assessment covering all RCHEs
The annual surveys cover all RCHEs in Hong Kong from 2005 to 2014, based on the lists maintained by the licensing authority. ${ }^{4}$ The coverage rate was $98.5 \%$ to $100 \%$ from 2005 to 2014 . A few RCHEs were not covered because they were either non-operating (under renovation or recently closed) or refused the VHT service. These RCHEs were excluded from analysis.

\section{Data collection}

The surveys were conducted from August to October each year, based on an assessment protocol developed by doctors and nurses of the VHTs, and with reference to the $\mathrm{COP},{ }^{2}$ the prevailing "Guidelines on Prevention of Communicable Diseases in Residential Care Home for the Elderly" and overseas guidelines on infection control practice. $^{5-7}$ Resident demographics, staff profiles, information on environment and facilities related to infection control, and knowledge and skills of the ICO and other staff were collected in the surveys. The assessments were divided into four parts:

Part I: The characteristics and profiles of residents and staff of the RCHEs, including the subjective training needs of staff, were collected through a self-administered questionnaire (online supplementary Appendix) completed by the personin-charge of the RCHE, prior to the site visit by the VHT. 
Part II: The environmental conditions and facilities related to infection control in RCHEs were assessed by a VHT nurse during the site visit.

Part III: The health monitoring and record keeping practices in RCHEs were assessed during the site visit.

Part IV: The knowledge and skills on infection control of staff in RCHEs were assessed in face-toface interviews during the site visit. The ICO (or other staff, depending on the topic being assessed) of each RCHE was assessed. An additional member of staff (either a health worker or care worker) was also selected at random for assessment on hand washing technique.

After the assessments, data were either double-entered or double-checked by two separate colleagues. In addition, $10 \%$ of the questionnaires were audited by an independent colleague, who rechecked all questionnaires if the error rate detected was greater than $0.5 \%$ of data fields. Descriptive statistics on the characteristics of the residents and the health/personal care staff were tabulated. Categorical data were analysed by either Chi squared test or Fisher's exact test while trend analysis was conducted by linear regression. A linear trend is reported as significant when the slope of the regression line is statistically different from zero. All analyses were conducted using SPSS (Windows version 24.0; IBM Corp, Armonk [NY], United States). This report was prepared following the STROBE (Strengthening the Reporting of Observational Studies in Epidemiology) statement. ${ }^{8}$

\section{Results}

The majority of RCHEs (ranging from $73.9 \%$ to $75.7 \%$, between 2005 and 2014) were commercially operated RCHEs ("private RCHEs"). The remaining $24.3 \%$ to $26.1 \%$ were "non-private RCHEs", comprising those that received subsidies or subventions from the government and those that were non-profit making and self-financing in nature. ${ }^{9}$

\section{Part I: Characteristics of residents and staff of residential care homes for the elderly}

\section{Age profile of residents}

The age profile of the residents in RCHEs from 2005 to 2014 is shown in the Figure. An apparent ageing trend is observed with the proportion of $\mathrm{RCHE}$ residents aged $\geq 85$ years rising from $40.0 \%$ (23 718) in 2005 to $50.2 \%$ (31 149) in $2014(\mathrm{P}=0.002)$.

\section{Residents with special care needs}

Table 1 shows the percentage of residents with special care needs from 2005 to 2014 . The proportion of residents with dementia increased from $22.3 \%$ in 2005 to $32.6 \%$ in $2014(\mathrm{P}<0.001)$. The percentage of residents with a long-term indwelling urinary

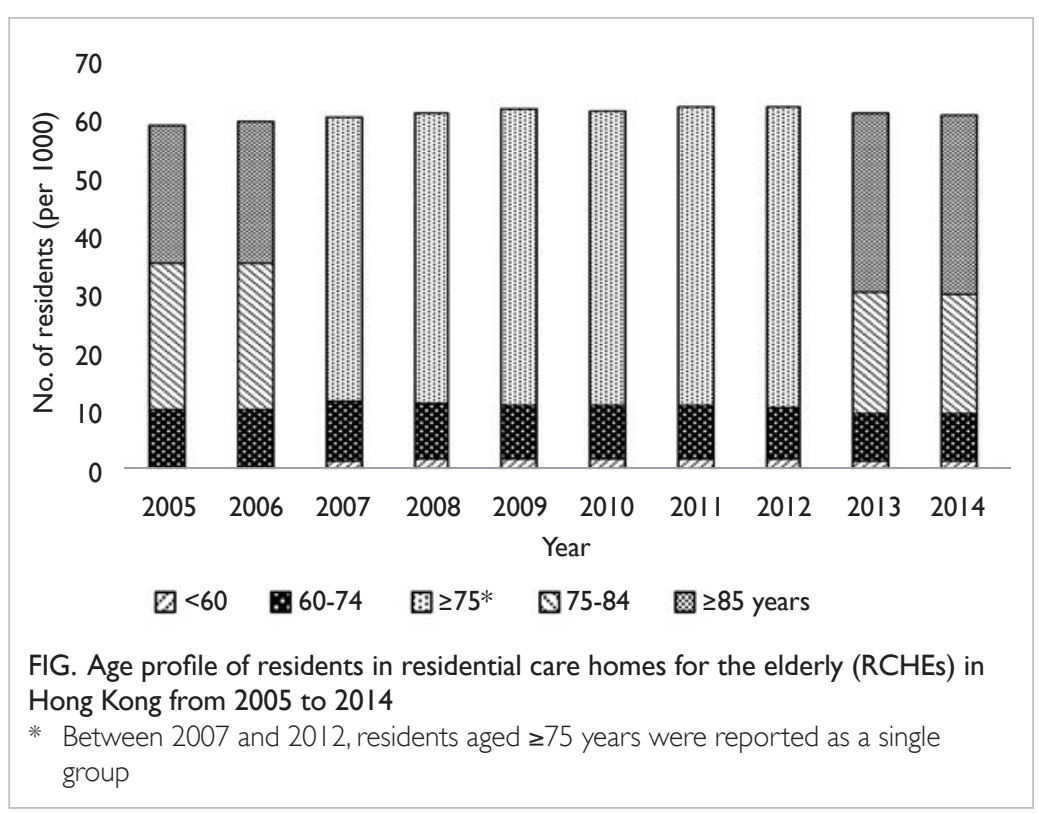

catheter increased from $3.4 \%$ in 2005 to $5.0 \%$ in $2014(\mathrm{P}<0.001)$, representing a $47 \%$ increase in the number of patients with a long-term indwelling urinary catheter.

\section{Manpower in residential care homes for the elderly}

The resident-to-staff ratios in RCHEs from 2005 to 2014 are shown in Table 2. The major types of staff in RCHEs in Hong Kong are professionally qualified nurses (including registered nurses and enrolled nurses registered under the Nursing Council of Hong Kong), health workers who have completed basic training recognised by the licensing authority, care workers who have not received any official training, and other staff including allied health and supporting staff. There were no significant changes in overall resident-to-staff ratio over the study period. For nurses and health workers, the overall manpower ratios improved from 30:1 and 27:1 in 2005 to $23: 1$ and $17: 1$ in 2014, respectively (both $\mathrm{P}<0.001)$. Increases in numbers of full-time and part-time nurses and health workers contributed to the improvements in these ratios.

There was an observable difference in terms of the number of nurses between private RCHEs and non-private RCHEs. In 2014, the resident-to-nurse ratio was 58:1 in private RCHEs compared with 11:1 in non-private RCHEs. In fact, the majority of private RCHEs (70.9\%) did not employ any nursing staff. In contrast, only $3.8 \%$ of non-private RCHEs did not have any nursing staff. Only $18.5 \%$ of private RCHEs had assigned nurses as ICOs, whereas the percentage was $93.0 \%$ in non-private RCHEs. The rest of the RCHEs appointed health workers as ICOs. 
TABLE I. Percentage of residents with special care needs in residential care homes for the elderly in Hong Kong from 2005 to 2014

\begin{tabular}{|c|c|c|c|c|c|c|c|c|c|c|c|}
\hline & \multicolumn{10}{|c|}{ No. $(\%)$ of residents } & \multirow{2}{*}{$\begin{array}{c}\text { Regression } \\
\text { coefficient }\end{array}$} \\
\hline & 2005 & 2006 & 2007 & 2008 & 2009 & 2010 & 2011 & 2012 & 2013 & 2014 & \\
\hline $\begin{array}{l}\text { Diagnosed with } \\
\text { dementia }\end{array}$ & $\begin{array}{c}13293 \\
(22.3 \%)\end{array}$ & $\begin{array}{c}14360 \\
(24.0 \%)\end{array}$ & $\begin{array}{c}14304 \\
(23.5 \%)\end{array}$ & $\begin{array}{c}15809 \\
(25.7 \%)\end{array}$ & $\begin{array}{c}15937 \\
(25.7 \%)\end{array}$ & $\begin{array}{c}17145 \\
(27.6 \%)\end{array}$ & $\begin{array}{c}17560 \\
(28.1 \%)\end{array}$ & $\begin{array}{c}18307 \\
(29.3 \%)\end{array}$ & $\begin{array}{c}18872 \\
(30.7 \%)\end{array}$ & $\begin{array}{c}19981 \\
(32.6 \%)\end{array}$ & $\begin{array}{c}716.68 \\
(P<0.001)\end{array}$ \\
\hline Bed-bound & $\begin{array}{c}7586 \\
(12.8 \%)\end{array}$ & $\begin{array}{c}7211 \\
(12.1 \%)\end{array}$ & $\begin{array}{c}8139 \\
(13.4 \%)\end{array}$ & $\begin{array}{c}7224 \\
(11.7 \%)\end{array}$ & $\begin{array}{c}8691 \\
(14 \%)\end{array}$ & $\begin{array}{c}8457 \\
(13.6 \%)\end{array}$ & $\begin{array}{c}8275 \\
(13.2 \%)\end{array}$ & $\begin{array}{c}8770 \\
(14 \%)\end{array}$ & $\begin{array}{c}8190 \\
(13.3 \%)\end{array}$ & $\begin{array}{c}8536 \\
(13.9 \%)\end{array}$ & $\begin{array}{c}130.16 \\
(P=0.03)\end{array}$ \\
\hline $\begin{array}{l}\text { On in-dwelling } \\
\text { urinary catheter }\end{array}$ & $\begin{array}{c}2012 \\
(3.4 \%)\end{array}$ & $\begin{array}{l}2255 \\
(3.8 \%)\end{array}$ & $\begin{array}{l}2365 \\
(3.9 \%)\end{array}$ & $\begin{array}{c}2697 \\
(4.4 \%)\end{array}$ & $\begin{array}{c}2642 \\
(4.3 \%)\end{array}$ & $\begin{array}{c}2734 \\
(4.4 \%)\end{array}$ & $\begin{array}{c}2857 \\
(4.6 \%)\end{array}$ & $\begin{array}{c}2938 \\
(4.7 \%)\end{array}$ & $\begin{array}{c}3029 \\
(4.9 \%)\end{array}$ & $\begin{array}{c}3058 \\
(5.0 \%)\end{array}$ & $\begin{array}{c}110.72 \\
(P<0.001)\end{array}$ \\
\hline
\end{tabular}

TABLE 2. Resident-to-staff manpower ratio in residential care homes for the elderly in Hong Kong from 2005 to 2014

\begin{tabular}{|c|c|c|c|c|c|c|c|c|c|c|c|}
\hline & \multicolumn{10}{|c|}{ No. of residents per staff (rounded figure) } & \multirow{2}{*}{$\begin{array}{l}\text { Regression } \\
\text { coefficient }\end{array}$} \\
\hline & 2005 & 2006 & 2007 & 2008 & 2009 & 2010 & 2011 & 2012 & 2013 & 2014 & \\
\hline All staff types & 3.0 & 3.0 & 3.0 & 3.0 & 3.0 & 3.0 & 3.0 & 3.0 & 3.0 & 3.0 & 0 \\
\hline Care worker & 6.3 & 6.1 & 5.8 & 5.8 & 5.6 & 5.6 & 5.6 & 5.6 & 5.7 & 5.6 & $-0.067(P=0.003)$ \\
\hline Health worker & 26.6 & 23.7 & 21.6 & 20.0 & 19.2 & 17.7 & 17.5 & 17.1 & 16.9 & 17.0 & $-1.00(P<0.001)$ \\
\hline Nurse & 30.4 & 32.8 & 29.8 & 30.1 & 29.5 & 28.4 & 28.0 & 25.6 & 23.8 & 22.5 & $-0.99(P<0.001)$ \\
\hline
\end{tabular}

Part II: Infection control-environment and facilities

\section{Common area}

The RCHEs are collective living places where communicable diseases can easily spread through contact with the environment. Therefore, it is essential for RCHEs to be equipped with proper facilities to prevent outbreaks. After years of promotion, the proportion of RCHEs with alcohol hand rub increased significantly from $25.4 \%$ in 2006 to $99.2 \%$ in 2014 ( $\mathrm{P}=0.008)$, as shown in Table 3. Nevertheless, further examination of a selected bottle of alcohol hand rub at each of the RCHEs revealed that, in 2014, only $92.4 \%$ of RCHEs had alcohol hand rub that had proper concentrations and were within the expiry dates. Although this was an improvement from $64.1 \%$ in 2008 , a difference in performance was observed in 2014, with only $90.7 \%$ of private RCHEs having proper alcohol hand rub, compared with 97.3\% of non-private RCHEs $(\mathrm{P}=0.003)$.

\section{Isolation area}

According to the COP for $\mathrm{RCHEs}^{2}$ an isolation facility is a basic requirement for an RCHE and is defined as "a designated area or room with good ventilation, adequate space for equipment for proper disposal of personal and clinical wastes, and basic hand hygiene and hand-drying facilities as well as electric call bell." The proportion of RCHEs equipped with a designated room as an isolation area for fever cases ranged from $73.6 \%$ to $80.0 \%$ between 2005 and 2014. No obvious trend was observed. In 2014, $19.9 \%$ and $0.8 \%$ of RCHEs were still only able to provide fixed boards of either three-quarters or half the height of the room, respectively, as partitions for the isolation area instead of providing separate rooms (Table 3). More non-private than private RCHEs were able to designate a separate room for isolation in 2014 ( $90.3 \%$ vs $73.3 \%, \mathrm{P}<0.05)$. However, of the rooms designated as isolation areas, $1.5 \%$ in non-private RCHEs and 5.3\% in private RCHEs were found to be occupied by residents without the need for isolation, or used for storage.

\section{Part III: Health monitoring and record keeping in residential care homes for the elderly}

For contact tracing and outbreak investigation, a proper record system is essential. Only $60.3 \%$ of all RCHEs kept proper visitors' record in 2005, increasing to $92.1 \%$ in 2014 . There were also moderate improvements in the maintenance of sick leave records for staff, fever records for residents, and training records on infection control for staff, as shown in Table 3 . However, a statistically significant trend could not be identified.

\section{Part IV: Infection control skills and practice}

The ICO's skill at hand washing, wearing and removing of personal protective equipment, and preparing bleach solution for environmental disinfection were tested in each RCHE. In addition to assessing the ICO, a health worker or care worker was also selected at random for hand washing technique auditing. The proportion of ICOs with proper hand washing technique increased from $86.7 \%$ in 2005 
TABLE 3. Performance on various infection control practices in residential care homes for the elderly (RCHEs) in Hong Kong from 2005 to 2014

\begin{tabular}{|c|c|c|c|c|c|c|c|c|c|c|c|}
\hline & \multicolumn{10}{|c|}{ No. (\%) of RCHEs } & \multirow{2}{*}{$\begin{array}{l}\text { Regression } \\
\text { coefficient } \\
\text { (P value) }\end{array}$} \\
\hline & 2005 & 2006 & 2007 & 2008 & 2009 & 2010 & 2011 & 2012 & 2013 & 2014 & \\
\hline \multicolumn{12}{|c|}{ Availability of alcohol hand rub } \\
\hline Alcohol hand rub available & NA & $\begin{array}{c}192 \\
(25.4 \%)\end{array}$ & $\begin{array}{c}187 \\
(24.3 \%)\end{array}$ & $\begin{array}{c}522 \\
(67.9 \%)\end{array}$ & $\begin{array}{c}731 \\
(94.6 \%)\end{array}$ & $\begin{array}{c}736 \\
(94.6 \%)\end{array}$ & $\begin{array}{c}728 \\
(93.5 \%)\end{array}$ & $\begin{array}{c}714 \\
(93.5 \%)\end{array}$ & $\begin{array}{c}727 \\
(97.5 \%)\end{array}$ & $\begin{array}{c}727 \\
(99.2 \%)\end{array}$ & $\begin{array}{c}69.02 \\
(P=0.008)\end{array}$ \\
\hline $\begin{array}{l}\text { Alcohol hand rub of proper } \\
\text { concentration }(70-80 \%) \text { and } \\
\text { not expired }\end{array}$ & NA & NA & NA & $\begin{array}{c}493 \\
(64.1 \%)\end{array}$ & $\begin{array}{c}627 \\
(81.1 \%)\end{array}$ & $\begin{array}{c}630 \\
(81 \%)\end{array}$ & $\begin{array}{c}605 \\
(77.7 \%)\end{array}$ & $\begin{array}{c}578 \\
(75.7 \%)\end{array}$ & $\begin{array}{c}642 \\
(86.1 \%)\end{array}$ & $\begin{array}{c}677 \\
(92.4 \%)\end{array}$ & $\begin{array}{c}18.93 \\
(P=0.08)\end{array}$ \\
\hline \multicolumn{12}{|c|}{ Different types of isolation areas } \\
\hline Separate room & $\begin{array}{c}555 \\
(73.6 \%)\end{array}$ & $\begin{array}{c}570 \\
(75.5 \%)\end{array}$ & $\begin{array}{c}589 \\
(76.6 \%)\end{array}$ & $\begin{array}{c}612 \\
(79.6 \%)\end{array}$ & $\begin{array}{c}596 \\
(77.1 \%)\end{array}$ & $\begin{array}{c}610 \\
(78.7 \%)\end{array}$ & $\begin{array}{c}618 \\
(79.3 \%)\end{array}$ & $\begin{array}{c}611 \\
(80.0 \%)\end{array}$ & $\begin{array}{c}583 \\
(78.2 \%)\end{array}$ & $\begin{array}{c}570 \\
(75.5 \%)\end{array}$ & $\begin{array}{c}2.23 \\
(P=0.08)\end{array}$ \\
\hline Fixed $3 / 4$ board & $\begin{array}{c}153 \\
(20.3 \%)\end{array}$ & $\begin{array}{c}150 \\
(19.9 \%)\end{array}$ & $\begin{array}{c}145 \\
(18.9 \%)\end{array}$ & $\begin{array}{c}126 \\
(16.4 \%)\end{array}$ & $\begin{array}{c}151 \\
(19.5 \%)\end{array}$ & $\begin{array}{c}139 \\
(17.9 \%)\end{array}$ & $\begin{array}{c}133 \\
(17.1 \%)\end{array}$ & $\begin{array}{c}113 \\
(14.8 \%)\end{array}$ & $\begin{array}{c}128 \\
(17.2 \%)\end{array}$ & $\begin{array}{c}150 \\
(19.9 \%)\end{array}$ & $\begin{array}{c}-2.01 \\
(P=0.19)\end{array}$ \\
\hline Fixed $1 / 2$ board & $6(0.8 \%)$ & $6(0.8 \%)$ & $1(0.1 \%)$ & $1(0.1 \%)$ & $6(0.8 \%)$ & $5(0.6 \%)$ & $7(0.9 \%)$ & $6(0.8 \%)$ & $8(1.1 \%)$ & $6(0.8 \%)$ & $\begin{array}{c}0.34 \\
(P=0.21)\end{array}$ \\
\hline No fixed isolation area & $\begin{array}{c}40 \\
(5.3 \%)\end{array}$ & $\begin{array}{c}29 \\
(3.8 \%)\end{array}$ & $\begin{array}{c}34 \\
(4.4 \%)\end{array}$ & $\begin{array}{c}30 \\
(3.9 \%)\end{array}$ & $\begin{array}{c}20 \\
(2.6 \%)\end{array}$ & $\begin{array}{c}21 \\
(2.7 \%)\end{array}$ & $\begin{array}{c}21 \\
(2.7 \%)\end{array}$ & $\begin{array}{c}34 \\
(4.5 \%)\end{array}$ & $\begin{array}{c}27 \\
(3.6 \%)\end{array}$ & $\begin{array}{c}29 \\
(3.8 \%)\end{array}$ & $\begin{array}{c}-0.84 \\
(P=0.26)\end{array}$ \\
\hline \multicolumn{12}{|c|}{ Availability of infection control-related records } \\
\hline Staff sick leave record & $\begin{array}{c}666 \\
(88.3 \%)\end{array}$ & $\begin{array}{c}688 \\
(91.1 \%)\end{array}$ & $\begin{array}{c}708 \\
(92.1 \%)\end{array}$ & $\begin{array}{c}701 \\
(91.2 \%)\end{array}$ & $\begin{array}{c}713 \\
(92.2 \%)\end{array}$ & $\begin{array}{c}730 \\
(93.8 \%)\end{array}$ & $\begin{array}{c}720 \\
(92.4 \%)\end{array}$ & $\begin{array}{c}683 \\
(89.4 \%)\end{array}$ & $\begin{array}{c}675 \\
(90.5 \%)\end{array}$ & $\begin{array}{c}667 \\
(91.0 \%)\end{array}$ & $\begin{array}{c}-0.81 \\
(P=0.77)\end{array}$ \\
\hline Visitor record & $\begin{array}{c}455 \\
(60.3 \%)\end{array}$ & $\begin{array}{c}632 \\
(83.7 \%)\end{array}$ & $\begin{array}{c}675 \\
(87.8 \%)\end{array}$ & $\begin{array}{c}675 \\
(87.8 \%)\end{array}$ & $\begin{array}{c}749 \\
(96.9 \%)\end{array}$ & $\begin{array}{c}717 \\
(92.2 \%)\end{array}$ & $\begin{array}{c}703 \\
(90.2 \%)\end{array}$ & $\begin{array}{c}691 \\
(90.4 \%)\end{array}$ & $\begin{array}{c}680 \\
(91.2 \%)\end{array}$ & $\begin{array}{c}675 \\
(92.1 \%)\end{array}$ & $\begin{array}{c}14.84 \\
(P=0.09)\end{array}$ \\
\hline Resident fever record & $\begin{array}{c}635 \\
(84.2 \%)\end{array}$ & $\begin{array}{c}702 \\
(93.0 \%)\end{array}$ & $\begin{array}{c}737 \\
(95.8 \%)\end{array}$ & $\begin{array}{c}740 \\
(96.2 \%)\end{array}$ & $\begin{array}{c}727 \\
(94.0 \%)\end{array}$ & $\begin{array}{c}721 \\
(92.7 \%)\end{array}$ & $\begin{array}{c}724 \\
(92.9 \%)\end{array}$ & $\begin{array}{c}714 \\
(93.5 \%)\end{array}$ & $\begin{array}{c}697 \\
(93.4 \%)\end{array}$ & $\begin{array}{c}706 \\
(96.3 \%)\end{array}$ & $\begin{array}{c}2.64 \\
(P=0.46)\end{array}$ \\
\hline $\begin{array}{l}\text { Infection control training } \\
\text { record }\end{array}$ & NA & NA & NA & $\begin{array}{c}645 \\
(83.9 \%)\end{array}$ & $\begin{array}{c}644 \\
(83.3 \%)\end{array}$ & $\begin{array}{c}659 \\
(84.7 \%)\end{array}$ & $\begin{array}{c}673 \\
(86.4 \%)\end{array}$ & $\begin{array}{c}636 \\
(83.2 \%)\end{array}$ & $\begin{array}{c}667 \\
(89.4 \%)\end{array}$ & $\begin{array}{c}656 \\
(89.5 \%)\end{array}$ & $\begin{array}{c}2.00 \\
(P=0.48)\end{array}$ \\
\hline \multicolumn{12}{|c|}{ Staff passing infection control skills tests } \\
\hline $\begin{array}{l}\text { Proper hand washing } \\
\text { technique (ICO) }\end{array}$ & $\begin{array}{c}654 \\
(86.7 \%)\end{array}$ & $\begin{array}{c}700 \\
(92.7 \%)\end{array}$ & $\begin{array}{c}701 \\
(91.2 \%)\end{array}$ & $\begin{array}{c}738 \\
(96.1 \%)\end{array}$ & $\begin{array}{c}737 \\
(95.3 \%)\end{array}$ & $\begin{array}{c}743 \\
(95.5 \%)\end{array}$ & $\begin{array}{c}752 \\
(96.5 \%)\end{array}$ & $\begin{array}{c}725 \\
(94.9 \%)\end{array}$ & $\begin{array}{c}715 \\
(95.8 \%)\end{array}$ & $\begin{array}{c}710 \\
(96.9 \%)\end{array}$ & $\begin{array}{c}4.71 \\
(P=0.14)\end{array}$ \\
\hline $\begin{array}{l}\text { Proper hand washing } \\
\text { technique (health/care } \\
\text { worker other than ICO) }\end{array}$ & NA & $\begin{array}{c}598 \\
(79.2 \%)\end{array}$ & $\begin{array}{c}628 \\
(81.7 \%)\end{array}$ & $\begin{array}{c}659 \\
(85.7 \%)\end{array}$ & $\begin{array}{c}671 \\
(86.8 \%)\end{array}$ & $\begin{array}{c}672 \\
(86.4 \%)\end{array}$ & $\begin{array}{c}677 \\
(86.9 \%)\end{array}$ & $\begin{array}{c}660 \\
(86.4 \%)\end{array}$ & $\begin{array}{c}679 \\
(91.0 \%)\end{array}$ & $\begin{array}{c}671 \\
(91.5 \%)\end{array}$ & $\begin{array}{c}7.55 \\
(P=0.02)\end{array}$ \\
\hline Dilution of bleach (ICO) & $\begin{array}{c}539 \\
(71.5 \%)\end{array}$ & $\begin{array}{c}582 \\
(77.1 \%)\end{array}$ & $\begin{array}{c}630 \\
(81.9 \%)\end{array}$ & $\begin{array}{c}652 \\
(84.8 \%)\end{array}$ & $\begin{array}{c}675 \\
(87.3 \%)\end{array}$ & $\begin{array}{c}673 \\
(86.5 \%)\end{array}$ & $\begin{array}{c}675 \\
(86.6 \%)\end{array}$ & $\begin{array}{c}678 \\
(88.7 \%)\end{array}$ & $\begin{array}{c}694 \\
(93.0 \%)\end{array}$ & $\begin{array}{c}676 \\
(92.2 \%)\end{array}$ & $\begin{array}{c}14.08 \\
(P=0.002)\end{array}$ \\
\hline $\begin{array}{l}\text { Donning and doffing of PPE } \\
\text { (ICO) }\end{array}$ & NA & $\begin{array}{c}609 \\
(80.7 \%)\end{array}$ & $\begin{array}{c}647 \\
(84.1 \%)\end{array}$ & $\begin{array}{c}637 \\
(82.8 \%)\end{array}$ & $\begin{array}{c}670 \\
(86.7 \%)\end{array}$ & $\begin{array}{c}655 \\
(84.2 \%)\end{array}$ & $\begin{array}{c}670 \\
(86.0 \%)\end{array}$ & $\begin{array}{c}650 \\
(85.1 \%)\end{array}$ & $\begin{array}{c}663 \\
(88.9 \%)\end{array}$ & $\begin{array}{c}635 \\
(86.6 \%)\end{array}$ & $\begin{array}{c}2.97 \\
(P=0.27)\end{array}$ \\
\hline
\end{tabular}

Abbreviations: ICO = infection control officer; $\mathrm{NA}=$ not available; PPE = personal protective equipment

to $96.9 \%$ in 2014, although a statistically significant mortality. Local data on infection control practices trend was not observed $(\mathrm{P}=0.14)$. However, an among RCHEs are limited. The current study is the improvement trend was observed for non-ICO first institution-based serial survey on the trend of health/care workers from $79.2 \%$ in 2006 to $91.5 \%$ infection control practices among RCHEs.

in $2014(\mathrm{P}=0.02)$ [Table 3]. The proportion of ICOs with proper skills on wearing and removing of personal protective equipment ranged from $80.7 \%$ to $88.9 \%$ between years 2006 and 2014 $(\mathrm{P}=0.27)$. The proportion of ICOs who were able to prepare bleach solution with the proper concentration showed an improving trend from $71.5 \%$ in 2005 to $92.2 \%$ in $2014(\mathrm{P}=0.002)$.

\section{Discussion}

Infectious disease outbreaks are major concerns for improvement was most obvious in terms of RCHEs as they often lead to significant morbidity and manpower and facilities. More nurses and health 
workers were recruited into RCHEs, and common areas equipped with alcohol hand rub. There was also a $10.2 \%$ improvement in hand washing skills and a $5.9 \%$ improvement on skills of wearing and removing of personal protective equipment among ICOs during the study period (Table 3). Possible contributory factors to such improvements may include the overall increased level of awareness on the importance of infection control, increased availability of manpower ${ }^{11-13}$ and financial resources, and improved access to infection control training programmes.

Despite the improvements in infection control, there are some areas of concern that are worth noting.

First, there was a sharp initial increase in the number of RCHEs that had separate rooms as isolation areas in 2004. This was likely an enhancement measure in response to the SARS outbreak in 2003. However, the proportion of RCHEs with separate isolation rooms has remained stable at around $70 \%$ since then, despite ongoing training and education. Possible explanations for this plateau include lack of space, other competing demands, and other resourcing issues.

A similar plateau effect was also observed for knowledge and skills on infection control measures. The RCHE staff's knowledge on the assessment items significantly improved (to near $90 \%$ for most topics), then showed little further improvement.

Non-private RCHEs consistently performed better than private RCHEs, especially in terms of nursing manpower, availability of proper isolation areas, and availability of effective alcohol hand rub. There is a fundamental funding difference between private and non-private RCHEs. In addition to complying with statutory requirements, government subvented RCHEs or those providing subsidised places (eg, RCHEs participating in bought place schemes) are also required to meet quality standards set out in the service contracts with the government. However, private RCHEs not participating in such schemes are only required to comply with the minimum statutory standards, such that service quality among private RCHEs remains variable. ${ }^{14}$

Moreover, the high staff turnover rate in the private sector may also explain why the performance of infection control in private RCHEs still lags behind that of non-private RCHEs, because knowledge and skills are not retained when trained care workers leave. ${ }^{15}$

There are several main limitations to our study. First, although RCHE staff have attained a generally adequate level of knowledge and skills on infection control, the implementation or the extent of adoption of these skills in daily practice could not be ascertained by our assessments which took the form of knowledge and skill tests rather than covert observation of real practice. In addition, the achieved results might not be representative, because the pre-scheduling allowed ample lead time for the staff of the RCHEs to prepare for the assessment. Unannounced visits and covert observation might provide a more accurate assessment of staff skill levels and the extent of application of such skills in daily practice, although covert observation itself may pose other practical challenges. ${ }^{16}$

Second, it was not feasible for us to interview all staff during our site visits, because the RCHEs must maintain routine service for residents. During site visits, we assessed the knowledge and practice of only the ICO and one additional health or care worker. The performance of these two selected workers might not be representative of all staff of the RCHE.

Third, to enhance comparability of assessment results, most questions asked and skills tested were similar between years. Thus, the assessment content might become predictable as the assessments were repeated annually. This might have led to survey fatigue and inability to capture true performance.

With an increasingly frail and ageing cohort of residents, $\mathrm{RCHEs}$ are expected to face a growing risk of infectious disease outbreaks in the coming decades, especially those involving multidrug-resistant organisms. Other than general infection control measures already adopted by the RCHEs, having a stable and well-trained workforce will become an increasingly important factor in determining the success of RCHEs in combating infectious diseases, especially as the number of elderly residents with special care needs (such as those with indwelling urinary catheters or on nasogastric feeding) is rising. Manpower planning, development, and staff retention will remain a challenge for infection control.

Moreover, as knowledge and skills on infection control have stopped improving, training on infection control should emphasise encouraging sustainability of vigilant practices. Measures including self-auditing on infection control should be considered, to encourage RCHE staff to monitor their own infection control performance on a regular basis, between annual external assessments.

\section{Conclusion}

This is the first territory-wide report on trends in infection control performance in RCHEs in Hong Kong. Data collected enabled us to understand the strengths and limitations in RCHEs on infection control, thus allowing stakeholders to design more targeted infection control training programmes.

Knowledge and skills on infection control have reached an adequate level and remained stable. Future infection control training should aim to support sustained compliance with proper practice, through introduction of elements such as self-audits. 


\section{Author contributions}

All authors had full access to the data, contributed to the study, approved the final version for publication, and take responsibility for its accuracy and integrity.

Concept or design: GCY Wong, T Ng, T Li.

Acquisition of data: GCY Wong.

Analysis or interpretation of data: GCY Wong.

Drafting of the article: GCY Wong.

Critical revision for important intellectual content: $\mathrm{T} \mathrm{Ng}, \mathrm{T}$ Li.

\section{Conflicts of interest}

The authors have disclosed no conflict of interest.

\section{Funding/support}

The report was funded by the Department of Health, Hong Kong.

\section{Ethics approval}

A waiver for ethical review was endorsed by the Ethics Committee of the Department of Health, Hong Kong.

\section{References}

1. Census and Statistics Department, Hong Kong SAR Government. 2016 Population By-census. Thematic report: older persons. Available from: https://www.bycensus2016. gov.hk/data/16BC_Older_persons_report.pdf. Accessed 8 Jan 2019.

2. Social Welfare Department, Hong Kong SAR Government. Code of practice for residential care homes (elderly persons). Available from: http://www.swd.gov.hk/doc/ LORCHE/CodeofPractice_E_201303_20150313R3.pdf. Accessed 8 Jan 2019.

3. Department of Health, Hong Kong SAR Government. Guidelines on prevention of communicable diseases in residential care home for the elderly (3rd edition). Available from: https://www.chp.gov.hk/files/pdf/guidelines_on prevention_of_communicable_diseases_in_rche_eng.pdf. Accessed 8 Jan 2019.

4. Social Welfare Department, Hong Kong SAR Government. List of residential care homes. Available from: https:// www.swd.gov.hk/en/index/site_pubsvc/page_elderly/sub_ residentia/id_listofresi/. Accessed 8 Jan 2019.

5. World Health Organization. WHO guidelines on hand hygiene in health care. Available from: http://apps.who.int/ iris/bitstream/handle/10665/44102/9789241597906_eng. pdf? sequence $=1$. Accessed 8 Jan 2019.

6. Audit tools for monitoring infection control guidelines within the community setting. Bathgate, UK: Infection Control Nurses Association; 2005.

7. Routine practices and additional precautions in all health care settings. Canada: Provincial Infectious Diseases Advisory Committee. Ministry of Health and Long-Term Care; 2009.

8. von Elm E, Altman DG, Egger M, Pocock SJ, Gøtzsche PC, Vandenbroucke JP; STROBE Initiative. The strengthening the reporting of observational studies in epidemiology (STROBE) statement: guidelines for reporting observational studies. PLoS Med 2007;4:e296.

9. Social Welfare Department, Hong Kong SAR Government. SWD elderly information website. Type of residential care homes. Available from: https://www.elderlyinfo.swd.gov. hk/en/rches_natures.html. Accessed 8 Jan 2019.

10. Büla CJ, Ghilardi G, Wietlisbach V, Petignat C, Francioli P. Infections and functional impairment in nursing home residents: a reciprocal relationship. J Am Geriatr Soc 2004;52:700-6.

11. Castle NG, Engberg J. The influence of staffing characteristics on quality of care in nursing homes. Health Serv Res 2007;42:1822-47.

12. Bostick JE, Rantz MJ, Flesner MK, Riggs CJ. Systematic review of studies of staffing and quality in nursing homes. J Am Med Dir Assoc 2006;7:366-76.

13. Bowers BJ, Esmond S, Jacobson N. The relationship between staffing and quality in long-term care: exploring the views of nurse aides. J Nurs Care Qual 2000;14:5564.

14. Hong Kong SAR Government's response to a question raised by a Legislative Councillor on 11 January 2017. Available from: https://www.info.gov.hk/gia/ general/201701/11/P2017011100501.htm. Accessed 28 Jan 2019.

15. Research Brief Issue No. 1 2015-2016, Research Office, Legislative Council Secretariat, Hong Kong. Available from: https://www.legco.gov.hk/research-publications/ english/1516rb01-challenges-of-population-ageing20151215-e.pdf. Accessed 8 Jan 2019.

16. Petticrew M, Semple S, Hilton S, et al. Covert observation in practice: Lessons from the evaluation of the prohibition of smoking in public places in Scotland. BMC Public Health 2007;7:204. 